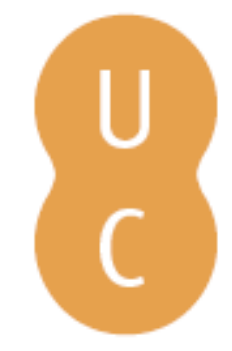

\title{
pommalina
}

\section{Identification of the multidimensional model of subjective time experience}

Autor(es): $\quad$ Flaska, Karel; Cakirpaloglu, Panajotis

Publicado por: Imprensa da Universidade de Coimbra

URL

persistente:

URI:http://hdl.handle.net/10316.2/38633

DOI:

DOI:http://dx.doi.org/10.14195/978-989-26-0775-7_29

Accessed : $\quad$ 26-Apr-2023 10:35:23

A navegação consulta e descarregamento dos títulos inseridos nas Bibliotecas Digitais UC Digitalis, UC Pombalina e UC Impactum, pressupõem a aceitação plena e sem reservas dos Termos e Condições de Uso destas Bibliotecas Digitais, disponíveis em https://digitalis.uc.pt/pt-pt/termos.

Conforme exposto nos referidos Termos e Condições de Uso, o descarregamento de títulos de acesso restrito requer uma licença válida de autorização devendo o utilizador aceder ao(s) documento(s) a partir de um endereço de IP da instituição detentora da supramencionada licença.

Ao utilizador é apenas permitido o descarregamento para uso pessoal, pelo que o emprego do(s) título(s) descarregado(s) para outro fim, designadamente comercial, carece de autorização do respetivo autor ou editor da obra.

Na medida em que todas as obras da UC Digitalis se encontram protegidas pelo Código do Direito de Autor e Direitos Conexos e demais legislação aplicável, toda a cópia, parcial ou total, deste documento, nos casos em que é legalmente admitida, deverá conter ou fazer-se acompanhar por este aviso. 


\section{INTERNATIONAL \\ STUDIES IN TIME \\ PERSPECTIVE}

MARIA PAULA PAIXÃO

JOSÉ TOMÁS DA SILVA

(COORD.)

VICTOR ORTUÑO

PEDRO CORDEIRO

(EDITORS)

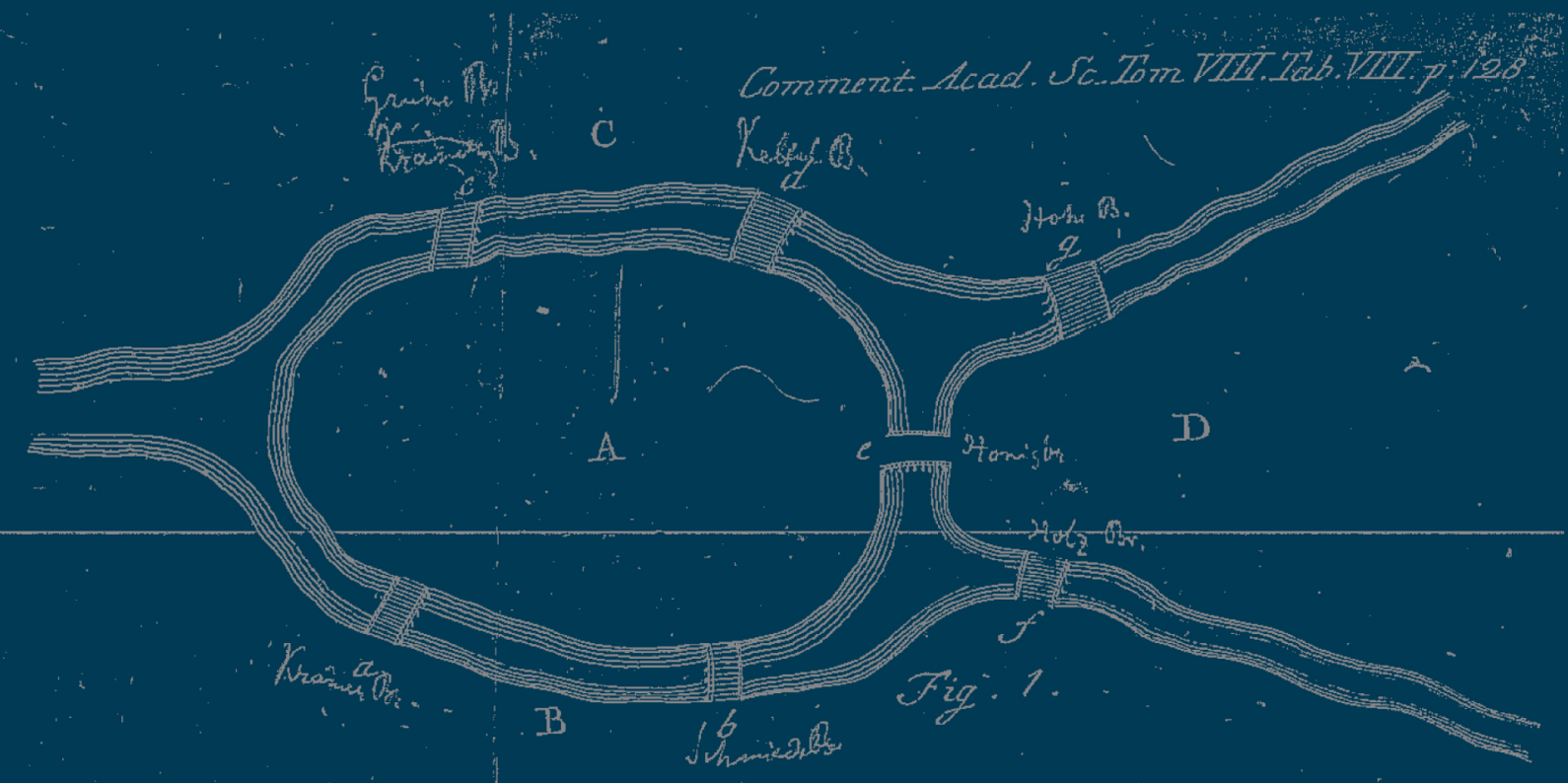

IMPRENSA DA

UNIVERSIDADE

DE COIMBRA

COIMBRA

UNIVERSITY

PRESS 
CHAPTER 29

Identification of the Multidimensional Model of SubJective Time Experience

\author{
Karel Flaska \\ Panajotis Cakirpaloglu \\ Department of Psychology, Philosophical Faculty of Palacky University, Czech Republic
}

\begin{abstract}
Aвstract: A comprehensive metaanalysis of empirical studies on the phenomenon of subjective time-distortion has provided strong evidence that a close relationship between subjective timedistortion occurrence and subjective significance (or emotional judgment) of stimulus exists. The authors suggest an original model of subjective time passage experience consisting of two bipolar dimensions - emotional judgment and perceived speed of time passage. Experimental and statistical verification of this model is the main objective of this study. Participants were 30 undergraduate students ( 15 males and 15 females) ranging in age from 20 to 26 years. Sophisticated experimental design based on the presentation of music samples with a specific emotion potential was developed. Actual emotional experience triggered by the music samples will be registered via semantic differential technique, together with retrospective time duration and time passage judgment. Eysenck Personality Questionnaire was also administrated. Data will be processed by variety of inductive statistics methods. The identified multidimensional model may significantly enrich many areas of psychological theory and practice. Above all, it is expected to provide valuable data for the development of a new psychodiagnostic method for affective disorders assessment.
\end{abstract}

Keywords: time, perception, emotionality, multidimensional model.

\title{
INTRODUCTION
}

\section{Paradigms in time experience research}

There are two most influential paradigms in time experience research, which need to be distinguished - the prospective and the retrospective paradigm (Block \& Zakay, 2010). While in prospective paradigm, the subjects are told in advance that they are expected to make time judgment, in the retrospective paradigm, the subjects are not aware of this fact (Block, 1990). There is a consensus among contemporary time researchers that they are saturated by different psychological mechanisms and that, for any proper progress in the field of time experience research, these two should not be confused (Wearden, 2005).

\section{Two basic types of subjective time experience}

Subjective time experience is accessible to experimental measurement in two basic modalities - time duration and time passage judgment. While time duration judgment can 
be defined as the subjective evaluation of duration length, time passage judgment can be defined as the perceived speed of time passage (Block, 1990; Wearden, 2005; Sucala et al. 2010; Sucala 2011).

According to some authors, these modalities are considered to be unrelated and supported by different cognitive mechanisms (Wearden, 2005). Luthman, Bliesener \& Staude-Müller (2009, p. 2) go yet further with their interpretations and in the introduction to their study, among other, claim that: "In verbal estimation task, a decreased subjective time flow will result in an underestimation of the standard time." In our opinion, it's too early to make premature interpretations of the relationship between the two types of subjective time experience for the lack of consistent empirical evidence. We appeal all researchers in the field of time experience to be more orderly and to avoid such "translations" between these two types of time experience until empirical evidence based "code" or "pattern" for such translation will be obtained.

As far as we know, the first two studies investigating the relationship of the two types of time experience under the same methodological conditions were conducted by Sucala et al. (2010) and Sucala, Scheckner and David (2010/2011). In the first study within retrospective paradigm, Sucala et al. (2010) reported no significant correlation between time duration and time passage judgments. On the other hand, within the prospective paradigm, Sucala et al. (2010/2011), found a significant correlation between time duration and time passage judgment indicating that a longer interval estimate is associated with a slower perceived speed of time passage.

\section{Emotionality and time experience}

Several studies on the effect of emotionality on prospective time duration judgment in general population has shown that people tend to overestimate emotionally loaded stimuli relative to neutral stimuli, and that stimuli with negative affective valence seem to last longer than positive or neutral stimuli (Droit-Volet, Brunot, \& Niedenthal, 2004; Noulhaine, Mella, Samson, Ragot, \& Pouthas, 2007).

\section{Enjoyment and boredom}

Up to date research on the effect of hedonic value of an activity on subjective time experience seems to provide empirical support for naive theories about time perception as: time flies when you have fun and drags when you are bored. Within retrospective paradigm, Sucala et al. (2010) investigated the relationship among time perception expectancies, the perception of time progression and perceived hedonic value of a task in virtual reality environment. They found significant difference in time passage judgments between "enjoyment expectancies" and "boredom expectancies" conditions, which implies that when people expect to have enjoyable experience, they perceive time as passing more quickly relative to boredom expectancy. However, results didn't show any significant effect of hedonic expectancies on time duration judgment.

\section{Arousal}

Angrilli, Cherubini, Pavese, and Manfredini (1997) reported on differential effect of stimulus arousal level. While for low-arousal stimuli the duration of negative stimuli was 
judged to be shorter relative to positive stimuli, for high-arousal stimuli condition, the duration of negative stimuli was judged to be longer relative to positive stimuli.

\section{Fear, anger and anxiety}

Langer, Wapner and Werner (1961) found shorter time duration judgments for subjects experiencing fear or danger relative to subjects in a neutral condition. On the other hand, Watts and Sharrock (1984) reported that spider-phobic subjects gave longer duration judgment of a short interval spent observing a spider relative to non-phobic subjects. Rinot and Zakay (2000) reported overestimation of the duration of aversive tones relative to neutral tones. Using the method of reproduction, Haim et al. (2010) reported longer duration judgments in anxious relative to non-anxious individuals when exposed to 2-second presentations of threat stimuli, but when exposed to neutral (calm) stimuli, no differences were found.

Gil and Droit-Volet (2011) found a relative overestimation of time for angry faces compared to the neutral faces in the temporal bisection, verbal estimation and production tasks, but not in the temporal generalization and reproduction tasks.

It's difficult to compare the findings because time distortions vary as a function of the presented emotional stimuli, with each stimulus having specific characteristics with regard to adaptation and timing (Gil \& Droit-Volet, 2011).

\section{Eysenck's basic dimensions of personality and time experience}

Existing studies (e.g. Eysenck, 1959; Claridge, 1960; Kirkcaldy, 1984; Rammsayer, 1997; or Rammsayer, 2002) on the relationship between Eysenck's basic dimensions of personality and time experience are quite rare and provide highly inconsistent results. All of the studies used only the time duration judgment as the measured variable. So far to our knowledge, there is no study on the relationship between Eysenck's dimensions of personality and perceived speed of time passage (time passage judgment).

\section{Extraversion and time estimation}

Using method of reproduction, Eysenck (1959) reported significant overestimation of 5 - and 10 -sec intervals in extraverted neurotics relative to introverted neurotics. Claridge (1960) reported highly significant correlations (ranging from $r=-0,51$ to $r=-0,66$ ) between extraversion and time errors, which indicates the same tendency to overreproduce time in extraverts relatively to introverts. Similarly, Lynn (1961) also found larger negative time error (overproduction, or overestimation) in extraverts relative to introverts. However, this effect was found only in the last three of 10 trials. Zakay, Lomranz and Kaziniz (1984) also found that extraverts overestimated the duration of simple figures relative to introverts, but there was no difference between the groups, when complex stimuli were used. On the other hand, some studies indicate the tendency to underestimate time duration in extraverts relative to introverts. Finally, there are also studies where no significant relationship between extraversion and time estimation was found (Bachorowski \& Newman, 1985; Du Preez, 1964; Gray, Gray, \& Loehlin, 1975; Kirkcaldy, 1984; Orme, 1962; Rammsayer, 1997; Rammsayer, 2002, Reed \& Kenna, 1964). 


\section{Neuroticism (emotional lability) and time estimation}

Similar inconsistency in results can be found in studies on the relationship between neuroticism and time duration judgment. While Davidson and House (1982) found tendency to overestimate time duration in low neuroticism subjects relative to high neuroticism subjects, Kirkcaldy (1984) found a consistent, but not significant, negative correlation between neuroticism and time duration judgments. Results of remaining studies suggest that neuroticism and time duration judgment are unrelated (Du Preez, 1967; Rammsayer, 1997; Rammsayer 2002).

\section{Psychoticism and time estimation}

Studies on the effect of psychoticism on time duration judgment are extremely rare. Thanks to different methodology applied, neither their results can be compared. Using the method of production, Kirkcaldy (1984) found significant negative correlation between psychoticism and time duration estimation of 60 -sec time interval in females. Using the method of reproduction, Rammsayer (1997) reported significant positive correlation between psychoticism and time duration judgment of 5- to 45-sec auditory intervals in males, which implies that males with higher psychoticism are more accurate and less vulnerable to overestimation than lower psychoticism males, since both groups overestimated. Finally, in his later work applying the method of comparison, Rammsayer (2002) revealed much better performance (greater accuracy/lower overestimation) on time duration judgments in the range of seconds in high psychoticism than in low psychoticism male subjects. In the range of milliseconds, no significant relationship between any of Eysenck's basic dimensions of personality was found in his male subjects.

\section{Review of present research project}

\section{Relativistic approach to subjective time experience}

Flaska (2011) introduced an original relativistic approach to the phenomenon of psychological time distortion inspired by Einstein's theory of relativity, which could provide a unifying framework to all the contradictory and incomparable results of subjective time experience research. He noticed that, despite all the inconsistencies in empirical results, one common denominator in the background of the phenomena of subjective time distortion can always be found - emotionality, or more generally subjective meaning. This finding can be formed into a general thesis: "Always there, where relative change in subjective meaning (emotionality) occurs, subjective time distortion (relative change in subjective time duration, or speed judgment) occurs as well." However, this thesis among others implies that a model of distorted semantic space-time continuum, where each subjective event would have its specific semantic position and specific "local" subjective time (passage or duration), could be developed. This is also the first objective of this study, which can be transformed into two separate following hypotheses:

Hypothesis 1: "A subjective time experience (time duration or time speed judgment) during a specific event and a specific position of this event in subjective semantic space are mutually dependent variables."

Hypothesis 2: "Apsychologicalrelativistic modelofsemanticspace-time continuum can be developed." 
Data for such semantic space-time continuum model could be easily obtained factorising data gained via semantic differential technique (e.g. in Osgood et al., 1957) and procedures commonly used to measure subjective time experience (e.g. in Gil \& DroitVolet, 2011). As the two basic types of subjective time experience can be simultaneously measured only via retrospective verbal estimation task, the framework of retrospective paradigm and verbal estimation task procedure were employed in our present study.

The choice of retrospective framework and simultaneous exploration of the two basic types of time experience under the same methodological conditions constitutes also the necessity to verify findings of Sucala et al. (2010), who reported statistical unrelatedness of the two types. Therefore, in correspondence with their findings, another hypothesis needs to be formulated:

Hypothesis 3: "Within the retrospective paradigm, time speed and time duration judgments are unrelated, and supported by different psychological mechanisms."

\section{Two-dimensional model of subjective time passage experience}

When we formulated the general thesis on the relationship between emotionality (subjective meaning) and time-distortion, we left out the directionality of the relationship (overestimation/underestimation or higher/lower speed of time passage), although existing studies seem to indicate such directionality - that the subjective time duration lengthens and subjective time passage slows down when relatively unpleasant (fearful, stressful, boring etc.) stimulus is presented. These results can definitely be taken as valid, but only for limited amount of types of subjective time passage experience. From this point on, we are going to narrow our considerations only to time passage type of time experience, to avoid translations of results between the two basic types (time duration and time passage experience).

To our knowledge, there's for example no study reporting on accelerated speed of subjective time passage in an unpleasant emotional state, which is maybe the most typical and equally the most problematic quality of time experience of modern western culture man. Contradictory, research reports on the decelerated speed of subjective time passage in a pleasant emotional state and supporting mechanisms as well are of the same or even higher importance, particularly for psychotherapy purposes. Therefore, we would like to propose a new descriptive model of subjective time passage experience that is able to cover all the four basic types of subjective time passage experience (see Figure 1a). The model consists of two basic dimensions - quantitative (the measure of subjective time passage acceleration or deceleration) and qualitative (the rudimentary system of emotional judgment - the aversion-appetence system). Since, the general emotional judgment dimension is expected to fragment into several subdimensions with specific relationship to the quantitative dimension of time passage experience, where some dimensions of this evaluative system are responsible for acceleration of subjective time passage, and others are responsible for deceleration of subjective time passage. Identification and differentiation of these subdimensions could become the main direction of future research in the field of subjective time passage experience. This also results in our fourth hypothesis:

Hypothesis 4: There are subdimensions of emotional judgment, where aversive judgment accelerates the subjective time passage. 
Figure $1 \mathrm{a}$ and $1 \mathrm{~b}$ shows the similarity of the suggested two-dimensional model of subjective time experience with the Eysenck's two-dimensional model of temperament (e.g. in Eysenck \& Eysenck, 1975). In our opinion, the similarity is not accidental, but rather necessary, and results from the nature of temperament concept, which can be defined as a relatively stable (biological) disposition to specific contents and dynamics of emotional reactions. Proceeding from the assumption that every dynamics presupposes a change, and that every change presupposes time, then every theory of subjective time experience must also contribute to the theory of temperament. These speculations logically imply our last two experimental hypotheses:

Hypothesis 5: The neuroticism (emotional lability) dimension significantly correlates with the qualitative (emotional judgment) dimension.

Hypothesis 6: The extraversion dimension significantly correlates with the quantitative (time speed passage) dimension.

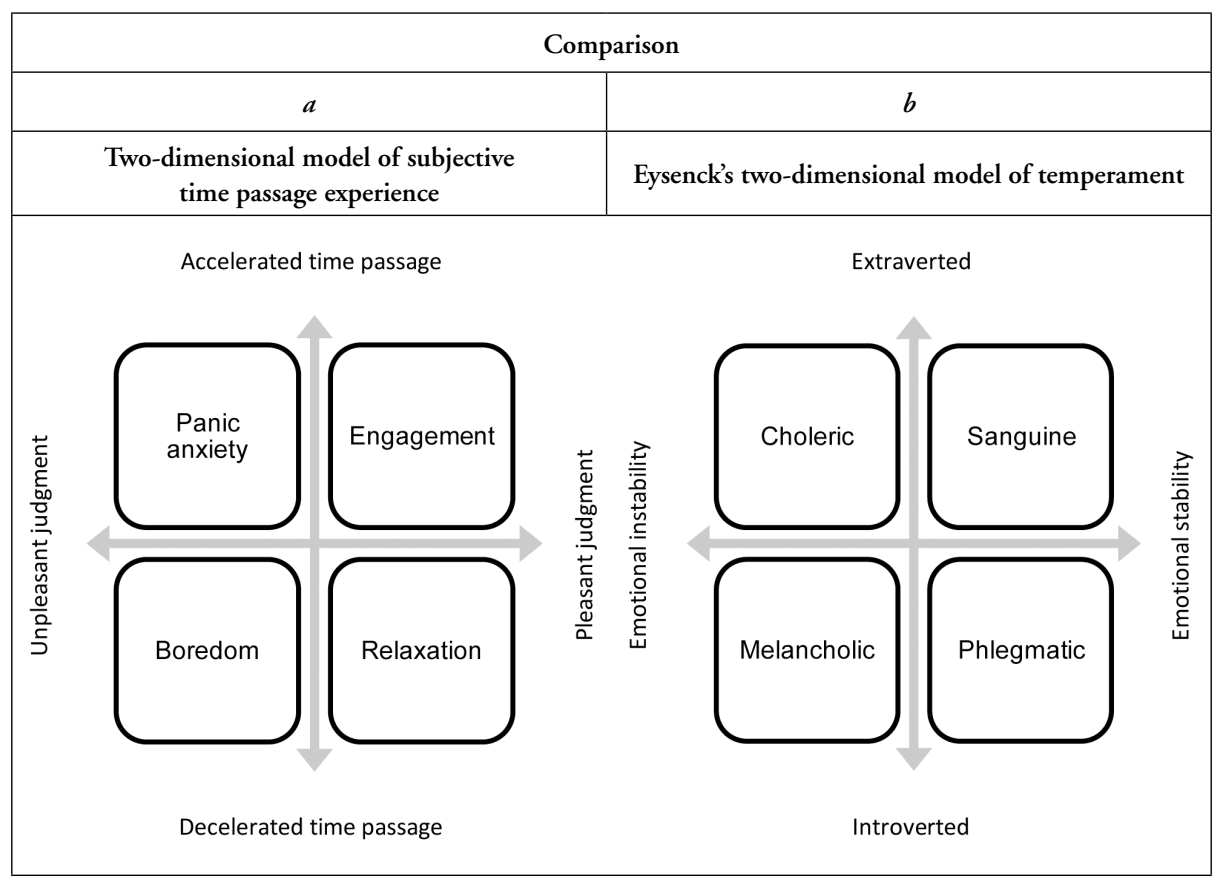

Figure 1. Comparison between the proposed two-dimensional model of subjective time passage experience and Eysenck two-dimensional model of temperament.

\section{SAmple \& Method}

\section{Participants}

Participants were 30 undergraduate students (15 males and 15 females) ranging in age from 20 to 26 years (mean age $=21.9$ years, $S D=1.32$ ). Each participant was rewarded 
with $200 \mathrm{CZK}$, as compensation for the time spent in the experiment. Informed consent was obtained before the experiment started.

\section{Stimuli and apparatus}

The battery of experimental stimuli consisted of 29 complex instrumental music samples and 1 simple tone $(f=528 \mathrm{~Hz})$. All the 30 samples were presented in the same order and with the same standard duration of 60 seconds. The auditory stimuli were presented through Bose SoundLink Black multi-room sound system wirelessly connected with PC. Successive presentation of music samples was controlled through music player Winamp (version 5.572).

The complex instrumental music samples were grouped into 5 categories with working title: (1) Sanguine (5 samples), (2) Melancholic (5 samples), (3) Choleric (5 samples), (4) Phlegmatic (5 samples), and (5) Horror (4 samples). These five groups were constituted with the requirement that the sample within the groups 1-4 triggered specific emotional states corresponding with the characteristics of four Galen temperament types, described for example in Eysenck and Eysenck (1975), and that the samples in the Horror group (5) triggered feelings of fear, tension, or anxiety. Placing a sample into one of the categories was conditioned by inter-subjective agreement of 2 independent collectors.

\section{Procedure}

Administration of the experiment was strictly individual to secure anonymity of the participants, and safe and confidential environment. Participants were told that the objective of the experiment is to explore relationship between music perception and personality characteristics. They were not told in advance that they are expected to make time judgments. There were also no clocks in the experimental room. If needed, participants were also asked to turn off their mobile phones and take off their wrist-watch.

After subscribing the informed consent, participants filled in the short version (48 items) of Czech adaptation of Eysenck Personality Questionnaire-Revised (EPQ-R; Eysenck \& Eysenck, 1975), containing four scales: Extraversion (12 items), Neuroticism (12 items), Psychoticism (12 items) and Lie/Social Desirability (12 items).

Following experimental session began with this instruction: "There are 30 sheets laid printed page down, one for each music sample, on the corner of the table. Your only task is to seat yourself comfortably, listen to the music samples and let them impress on you. Only after each music sample ends, you are supposed to take the sheet, fill it in and give it back to me. Now, I show you how to fill the sheet..." Then, the participants were instructed how to register and differentiate their impression via semantic differential technique applied. Individual adaptation of volume was made on a non-experimental sample, before the first experimental sample was presented. The experimental music samples were presented in the constant successive order corresponding with the above mentioned numbers of groups. Simple tone $(528 \mathrm{~Hz})$ was interposed as the $15 \mathrm{th}$, between the foregoing "Phlegmatic" (No. 14) and the following "Horror" (No. 16) sample. 


\section{Measures}

Dependent subjective time variables registered in this study were retrospective time duration (measured in seconds) and retrospective time speed (measured on a 7-point Likerttype scale) judgments. Dependent emotional judgment variables were measured via 25 7-point Likert-type scales of semantic differential technique.

\section{RESULTS}

To test the first two hypotheses, exploratory factor analysis was computed both for semantic differential scales and for stimuli music samples. Table 1 shows the results of exploratory factor analysis computed for the 25 scales of semantic differential. There were 4 main factors identified - Evaluation, Stress, Activity and Predictability. To maximize the reliability of the 4 obtained factors, Cronbach alpha values for each set of the most loaded factor scales was also computed. This process resulted in selection of 15 scales for further statistical analysis (see Table 2).

Relative average positions of the 30 music samples in the semantic space (Figure 1) together with variations of mean time speed judgment (Table 3 ) indicate that these could be mutually dependent variables, as our first hypothesis suggest, and that the data from Figure 1 and Table 3 together represent a real relativistic model of semantic space-time continuum. For statistical verification of this semantic time-space relationship, basic linear regression was computed. The results show that time speed judgment significantly correlates with all the four factors of semantic differential, as can be seen in Table 4, indicating that positive evaluation, low level of stress, high level of perceived activity and low level of predictability result in accelerated speed of time passage, while the opposite levels result in decelerated speed of time passage. There was also found significant, but much lower, correlation between time duration judgment and two of the four factors of semantic differential, indicating that positive evaluation and low level of perceived activity decrease the time duration estimation.

Pearson correlation coefficient between time duration and time speed judgment variables was not significant $\left(r_{x y}=0.03 ; p>0.05\right)$, indicating that the two types of time experience are unrelated within the retrospective paradigm.

Concerning the effect of Eysenck basic personality dimensions on time experience (see Table 5), results of correlation analysis showed that time duration judgment significantly correlated with extraversion and psychoticism, indicating that high level of extraversion is associated with greater tendency for relative underestimation (shorter time duration judgment), while high level of psychoticism is associated with greater tendency for relative overestimation (longer duration judgment) and also with greater accuracy (because the research group as a whole tended to pervasive underestimation). Contradictory, no significant correlation between any of Eysenck personality dimensions and time speed judgment was found.

Finally, we did not find any significant correlation among any of Eysenck personality dimensions and factors of semantic differential (emotional judgment), except the highly significant correlation between extraversion and evaluative factor, indicating that high level of extraversion is associated with more positive evaluation of the presented stimuli. 
Table 1 - Varimax row rotated PCA (principal component analysis) factor loadings for 30 undergraduate students on 30 stimuli samples

\begin{tabular}{|c|c|c|c|c|}
\hline \multirow{2}{*}{ Scale } & FACTOR 1 & FACTOR 2 & FACTOR 3 & FACTOR 4 \\
\hline & Evaluation & Stress & Activity & Predictability \\
\hline pleasant-unpleasant & .59 & .62 & .18 & .05 \\
\hline happy-sad & -.03 & .38 & .78 & .13 \\
\hline exciting-calming & -.01 & -.55 & .61 & -.01 \\
\hline restful-challenging & .08 & .77 & .01 & .16 \\
\hline intelligible-unintelligible & .47 & .51 & .13 & .32 \\
\hline ugly-beautiful & -.79 & -.44 & -.02 & .00 \\
\hline valuable-worthless & .87 & .12 & -.04 & -.03 \\
\hline interesting-boring & .81 & .07 & .18 & -.21 \\
\hline slow-fast & .03 & .12 & -.86 & .02 \\
\hline meaningful-meaningless & .79 & .28 & -.04 & .01 \\
\hline active-passive & .29 & -.09 & .78 & -.01 \\
\hline tense-relaxed & -.12 & -.87 & -.08 & -.09 \\
\hline safe-dangerous & .22 & .86 & .04 & .13 \\
\hline stable-unstable & .22 & .59 & -.10 & .43 \\
\hline inert-lively & -.29 & -.22 & -.77 & .20 \\
\hline satisfied-unsatisfied & .20 & .79 & .26 & .18 \\
\hline predictable-unpredictable & -.06 & .39 & .02 & .79 \\
\hline closed-open & -.13 & -.39 & -.51 & .25 \\
\hline violent-peaceful & -.14 & -.85 & .13 & -.09 \\
\hline successful-unsuccessful & .69 & .31 & .29 & .15 \\
\hline significant-insignificant & .86 & -.01 & .05 & .04 \\
\hline strong-weak & .70 & -.30 & .13 & -.05 \\
\hline known-unknown & .56 & -.06 & .18 & .45 \\
\hline variable-invariable & .21 & -.30 & .32 & -.64 \\
\hline like-dislike & .81 & .34 & .16 & -.04 \\
\hline Percent of Total Variance & 25 & 24 & 15 & 7 \\
\hline
\end{tabular}


Table 2 - Review of the 15 most factor loaded scales together with Cronbach alpha $v$ alues for each factor group of scales

\begin{tabular}{|c|c|c|c|c|}
\hline Factor & Evaluation & Stress & Activity & Predictability \\
\hline & ugly-beautiful & tense-relaxed & happy-sad & predictable-unpredictable \\
\hline & valuable-worthless & safe-dangerous & slow-fast & variable-invariable \\
\hline & interesting-boring & satisfied-unsatisfied & active-passive & \\
\hline $\begin{array}{c}\text { Cronbach } \\
\text { alpha }\end{array}$ & significant-insignificant & violent-peaceful & inert-lively & \\
\hline
\end{tabular}

\section{Average semantic space positions of the 30 music samples} on 15 selected scales of semantic differential

Rotation: Varimax raw

Extraction: Principal Component Analysis (PCA)

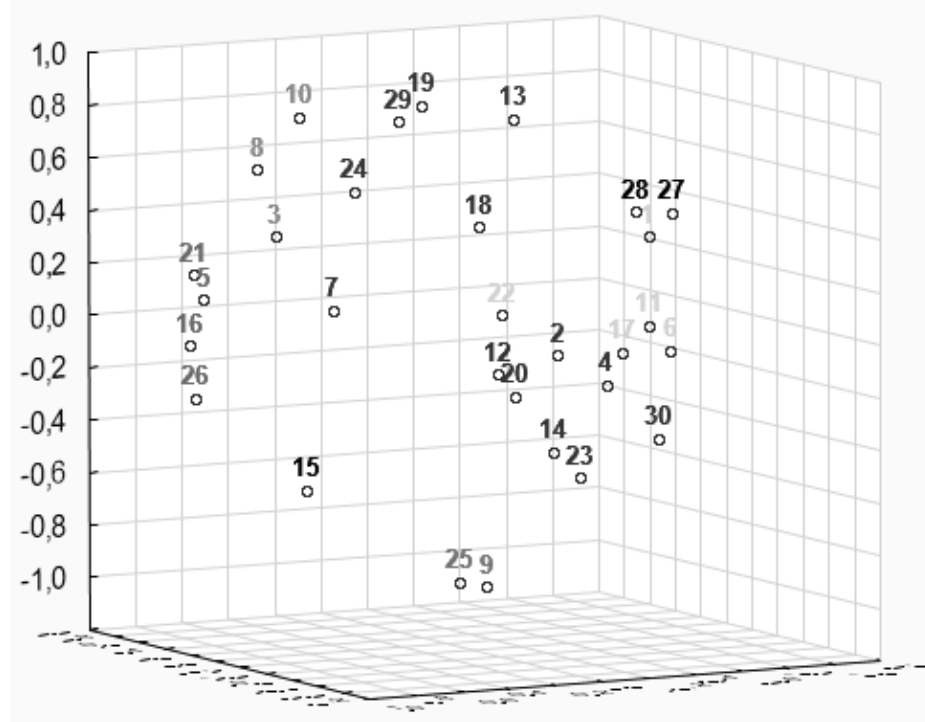

Figure 1. Average 3D semantic space positions of the 30 music samples on the 15 most factor loaded scales of semantic differential. 
Table 3 - Review of factor groups for the original set of 30 stimuli samples counted from positions on the 15 most factor loaded scales of semantic differential, together with mean time speed judgment (Mean TSJ) value of each sample on a 7-point Likert type scale ranging from 1 (extremely fast) to 7 (extremely slow)

\begin{tabular}{|c|c|c|c|c|c|c|c|c|c|}
\hline \multirow[t]{2}{*}{ Group } & \multicolumn{3}{|c|}{ Sanguine 1} & \multicolumn{3}{|c|}{ Phlegmatic 1} & \multicolumn{3}{|c|}{ Choleric 1} \\
\hline & No. & Work title & $\begin{array}{c}\text { Mean } \\
\text { TSJ }\end{array}$ & No. & Work title & $\begin{array}{c}\text { Mean } \\
\text { TSJ }\end{array}$ & No. & Work title & $\begin{array}{c}\text { Mean } \\
\text { TSJ }\end{array}$ \\
\hline & 1 & Sanguine & 2.9 & 2 & Melancholic & 4.1 & 3 & Choleric & 3.5 \\
\hline & 6 & Sanguine & 3.6 & 4 & Phlegmatic & 4.8 & 8 & Choleric & 4.2 \\
\hline & 11 & Sanguine & 3.0 & 14 & Phlegmatic & 4.2 & 10 & Horror & 3.9 \\
\hline & 17 & Sanguine & 3.1 & 23 & Melancholic & 4.2 & & & \\
\hline & 22 & Sanguine & 3.3 & 30 & Phlegmatic & 4.0 & & & \\
\hline \multirow[t]{6}{*}{ Group } & \multicolumn{3}{|c|}{ Sanguine 2} & \multicolumn{3}{|c|}{ Phlegmatic 2} & \multicolumn{3}{|c|}{ Choleric 2} \\
\hline & No. & Work title & $\begin{array}{c}\text { Mean } \\
\text { TSJ }\end{array}$ & No. & Work title & $\begin{array}{c}\text { Mean } \\
\text { TSJ }\end{array}$ & No. & Work title & $\begin{array}{c}\text { Mean } \\
\text { TSJ }\end{array}$ \\
\hline & 27 & Sanguine & 3.2 & 9 & Phlegmatic & 5.2 & 13 & Choleric & 2.9 \\
\hline & 28 & Melancholic & 3.1 & 25 & Phlegmatic & 4.6 & 19 & Choleric & 3.6 \\
\hline & & & & & & & 24 & Choleric & 3.6 \\
\hline & & & & & & & 29 & Choleric & 3.8 \\
\hline \multirow[t]{6}{*}{ Group } & \multicolumn{3}{|c|}{ Melancholic } & \multicolumn{3}{|c|}{ Horror } & \multicolumn{3}{|c|}{ Simple Tone $(528 \mathrm{~Hz})$} \\
\hline & No. & Work Title & $\begin{array}{c}\text { Mean } \\
\text { TSJ }\end{array}$ & No. & Work title & $\begin{array}{c}\text { Mean } \\
\text { TSJ }\end{array}$ & No. & Work title & $\begin{array}{c}\text { Mean } \\
\text { TSJ }\end{array}$ \\
\hline & 7 & Melancholic & 4.6 & 5 & Horror & 4.8 & 15 & Tone $(528 \mathrm{~Hz})$ & 5.6 \\
\hline & 12 & Melancholic & 3.9 & 16 & Horror & 4.5 & & & \\
\hline & 18 & Melancholic & 4.0 & 21 & Horror & 4.2 & & & \\
\hline & 20 & Phlegmatic & 4.0 & 26 & Horror & 4.8 & & & \\
\hline
\end{tabular}

Table 4 - Pearson correlation coefficients between the time duration and time speed judgment variables and weighted scores on the 4 factors of semantic differential $\left({ }^{*} p<0.05 ;{ }^{* *} p<0.01 ;{ }^{* * *} p<0.001\right)$

\begin{tabular}{|l|c|c|c|c|}
\hline & $\begin{array}{c}\text { FACTOR 1 } \\
\text { (Evaluation) }\end{array}$ & $\begin{array}{c}\text { FACTOR 2 } \\
\text { (Stress) }\end{array}$ & $\begin{array}{c}\text { FACTOR 3 } \\
\text { (Activity) }\end{array}$ & $\begin{array}{c}\text { FACTOR 4 } \\
\text { (Predictability) }\end{array}$ \\
\hline Time Duration Judgment & $-.06^{*}$ & .02 & $.12^{* *}$ & .01 \\
\hline Time Speed Judgment & $.36^{* * *}$ & $-.17^{* * *}$ & $.46^{* * *}$ & $-.10^{* *}$ \\
\hline
\end{tabular}


Table 5 - Pearson correlation coefficients between the scores on Eysenck personality dimensions and time duration and time passage judgments, and the weighted scores on the 4 factors of emotional judgment $\left({ }^{* * *} p<0.001\right)$

\begin{tabular}{|l|c|c|c|c|c|c|}
\hline & $\begin{array}{c}\text { Time Duration } \\
\text { Judgment }\end{array}$ & $\begin{array}{c}\text { Time Speed } \\
\text { Judgment }\end{array}$ & $\begin{array}{c}\text { FACTOR 1 } \\
\text { (Evaluation) }\end{array}$ & $\begin{array}{c}\text { FACTOR } \\
\text { 2 (Stress) }\end{array}$ & $\begin{array}{c}\text { FACTOR 3 } \\
\text { (Activity) }\end{array}$ & $\begin{array}{c}\text { FACTOR 4 } \\
\text { (Predictability) }\end{array}$ \\
\hline Extraversion & $-.45^{* * *}$ & -.05 & $.14^{* * *}$ & -.02 & -.03 & -.01 \\
\hline Neuroticism & .02 & -.02 & .03 & -.00 & .03 & .01 \\
\hline Psychoticism & $.21^{* * *}$ & .00 & .03 & .04 & -.01 & -.02 \\
\hline
\end{tabular}

\section{Discussion}

The results of our study seems to provide strong evidence (supporting our first two hypotheses) that, within the retrospective paradigm, time passage experience and emotional judgment (or subjective meaning) are mutually dependent variables, which both together constitute semantic space-time continuum, where perceived speed of time passage can be (at least partially) predicted from a relative position of an event in a semantic space, and vice versa. The factor analysis of the raw semantic differential data revealed that the general emotional judgment factor falls into 4 main factors (Evaluation, Stress, Activity and Predictability). All of them highly significantly correlated with time speed judgment. While negative evaluation, higher level of stress, lower activity and higher predictability are associated with decelerated speed of subjective time passage, positive evaluation, lower level of stress, higher activity and low predictability are associated with accelerated speed of subjective time passage. Two out of the four identified factors of emotional judgment (Evaluation and Activity) significantly correlated also with time duration judgment, but these correlations were much lower than in the case of time speed judgment. However, it seems that similar semantic space-time model (as introduced for the experience of time passage) could be developed also for the emotional judgment and time duration experience, but with different relationships between these two variables, which opens the discussion on the (un)relatedness of the two types of time experience investigated in this study.

The strongest evidence supporting the first part of hypothesis 3 that the two types of time experience are unrelated within the retrospective paradigm provided correlation analysis, which revealed no significant relationship between these two variables. This result can be taken as verification of the findings of Sucala et al. (2010), who also reported unrelatedness of the two types of time experience.

Correlations between the two types of time experience and factors of emotional judgment and Eysenck basic personality dimensions support also the second part of the hypothesis 3 that the two types of time experience are associated with different psychological mechanisms. While the time duration judgment seems to be more associated with personality differences (extraversion and psychoticism), time speed judgment seems to be unaffected by basic personality dimensions and much more correlated with perceived stimulus characteristic, respectively with high-level cognitive processes of emotional judgment or meaning attribution processes. In other words, these findings raise the question of personality versus situation influences on the subjective time experience. 
Moreover, the results of our study seem to question the emotional "neutrality" of stimuli commonly used in time research (e.g. Droit-Volet, Brunot, \& Niedenthal, 2004; Noulhaine, Mella, Samson, Ragot, \& Pouthas, 2007). Even the simple tone (sample No. 15), which could be taken as a "neutral" stimulus, evoked specific (extremely aversive) emotional judgment, which in turn resulted in extremely decelerated perceived speed of subjective time passage. For future research, these findings imply the necessity of consideration and evaluation of emotional characteristics of an employed stimulus.

Concerning the verification of the suggested model of subjective time passage experience, our study failed to find a dimension (or a scale) of emotional judgment, where explicitly negative emotional judgment would be associated with accelerated speed of subjective time passage. These facts call our suggested basic two-dimensional model of into question. Certain, but highly questionable, support for our fourth hypothesis represents the negative correlation between time speed judgment and predictability factor, indicating that unpredictable stimuli accelerate the perceived speed of time passage. The most questionable point is the aversive value of unpredictability. On the other hand, qualitatively considered, we succeeded in finding pleasant stimuli decelerating the perceived speed of time passage (samples No. 9 and 25). But it's necessary to mention that these two music samples were both perceived as sad. However, as was already mentioned, the values of time speed judgments are highly affected by the situational variables, namely by the characteristics of the stimulus presented, and thus by the experimental stimuli selection.

As the external validity of the basic four qualitative types of subjective time passage experience is undisputable, usage of more suitable methodological approach has to be considered. The main question is, whether listening of aversive music samples can put participants into aversive state with accelerated subjective time passage, or not. If yes, then different music samples have to be chosen. If the answer is not, then another methodological approach has to be chosen. Maybe an extreme (absurd) example of an aversive situation with undoubtedly accelerated time passage could provide the differential criterion. Let's imagine for example a hypothetical situation of a man, who has to deactivate a time bomb, having no idea how to do it, who cannot escape from the situation and who experiences it as a real situation (not fiction). Such description provides useful clues for construction of a suitable experimental situation with the same or at least similar characteristics (e.g. time limitation, high self-relevance, high task difficulty, exaggerating the repertoire of the subject's competences, and so on). This represents one of the possible ways of future research verifying the suggested two dimensional model of subjective time passage experience, containing the two exploratory neglected qualitative types of subjective time speed passage - time passage acceleration in unpleasant emotional states and time passage deceleration in pleasant emotional states.

Finally, similarity of the suggested two-dimensional model of subjective time passage experience with Eysenck two-dimensional model of temperament seems to be rather accidental. Significant correlation was neither found between neuroticism and any of the four identified factors of emotional judgment, nor between extraversion and time passage judgment. 


\section{ACKNOWLedgements}

This project is funded by the Internal Grant Agency of Palacky University (IGA PU project FF_2012_066). Special thanks to Tereza Capova for her help with experimental music sample battery composition.

\section{REFERENCES}

Angrilli, A., Cherubini, P., Pavese, A., \& Manfredini, S. (1997). The influence of affective factors on time perception. Perception \& Psychophysics, 59, 972-982.

Bachorowski, J. A., \& Newman, J. P. (1985). Impulsivity in adults: motor inhibition and timeinterval estimation. Personality and Individual Differences, 6, 133-136.

Bar-Haim, Y., Kerem, A., \& Lamy, D. (2010). When time slows down: The influence of threat on time perception in anxiety. Cognition and Emotion, 24 (2), 255-263.

Block, R. A. (1990). Models of psychological time. In R. A. Block (Ed.), Cognitive models of psychological time (pp. 1-35). Hillsdale, NJ: Lawrence Erlbaum Associates.

BLOCK, R. A., \& ZAKAY, D. (2001). Retrospective and prospective timing: Memory, attention, and consciousness. In C. Hoerl \& T. McCormack (Eds.), Time and memory: Issues in philosophy and psychology (pp. 59-76). Oxford, England : Oxford University Press.

Claridge, G. (1960). The excitation-inhibition balance. In H. J. Eysenck (Ed.), Experiments in personality (pp. 107-156). London: Routledge and Kegan Paul.

Droit-Volet, S., Brunot, S., \& Niedenthal, P. M. (2004). Perception of the duration of emotional events. Cognition and Emotion, 18, 849-858.

Du Preez, P. (1964). Judgment of time and aspects of personality. Journal of Abnormal and Social Psychology, 69, 228-233.

FLASKA, K. (2011) Aplikace matematického aparátu obecné teorie relativity na popis struktury osobnosti. Unpublished thesis. Olomouc: Psychology Department of Philosophical faculty of Palacky University.

GiL, S. \& Droit-Volet, S. (2011). “Time flies in the presence of angry faces”... depending on the temporal task used! Acta Psychologica, 136, 354-362.

Gray, C. T., Gray, C. R., \& Loehlin, J. C. (1975). Time perception: effects of introversion/ extraversion and task interest. Perceptual and Motor Skills, 41, 703-708.

Eysenck, H. J. (1959). Personality and the estimation of time. Perceptual and Motor Skills, 9, 405$-406$.

Eysenck, H. J. \& Eysenck, S. B. G. (1975). Manual of the Eysenck Personality Questionnaire. London: Hodder \& Stoughton.

KirkCaldy, B. D. (1984). Individual differences in time estimation. International Journal of Sport Psychology, 15, 11-24.

Langer, J., Wapner, S., \& Werner, H. (1961). The effect of Langer upon the experience of time. American Journal of Psychology, 74, 94-97.

LyNN, R. (1961). Introversion-extraversion in judgments of time. Journal of Abnormal and Social Psychology, 63, 457-458.

Noulhiane, M., Mella, N., Samson, S., Ragot, R., \& Pouthas, V. (2007). How emotional auditory stimuli modulate time perception. Emotion, 7, 697-704.

Orme, J. E. (1962). Time estimation and personality. Journal of Mental Science, 108, 213-216. 
Osgood, C. E., Suci, G. J. \& Tannenbaum, P. H. (1957). The measurement of meaning. Urbana: University of Illinois Press.

Rammsayer, T. H. (1997). On the relationship between personality and time estimation. Personality and Individual Differences, 23, 739-744.

Rammsayer, T. H. (2002). Temporal information processing and basic dimensions of personality: differential effects of psychoticism. Personality and Individual Differences, 32, 827-838.

Rinot, N., \& ZakaY, D. (2000). Prospective duration judgment and hedonic evaluation of Tome's sequences. Tel Aviv, Israel: Department of Psychology, Tel-Aviv University.

Reed, G. F., \& Kenna, J. C. (1964). Personality and time estimation in sensory deprivation. Perceptual and Motor Skills, 18, 182.

Sucala, M., Stefan, S., Szentagotai-Tatar, A. \& David, D. (2010). Time Flies When You Expect to Have Fun. An Experimental Investigation of the Relationship between Expectancies and the Perception of Time Progression. Cognition, Brain, Behavior. An Interdisciplinary Journal, 14, 231-241 .

Sucala, M., Scheckner, B. \& David, D. (2010/2011) Psychological Time: Interval Length Judgments and Subjective Passage of Time Judgments. Current psychology letters [Online], Vol. 26, Issue 2. Online since 08 février 2011. URL: http://cpl.revues.org/index4998.html

Watts, F. N., \& Sharrock, R. (1984). Fear and time estimation. Perceptual and Motor Skills, 59, 197-198.

Wearden, J. H. (2005). The wrong tree: Time perception and time experience in the elderly. In J. Duncan, L. Phillips, \& P. McLeod (Eds.), Measuring the mind: Speed, age, and control (pp. 137-158). Oxford: Oxford University Press.

Zakay, D., Lomranz, J., \& Kaziniz, M. (1984). Extraversion-introversion and time perception. Personality and Individual Differences, 5, 237-239. 